\title{
HISTORY OF FOREIGN LANGUAGE EDUCATION IN KARAKALPAK SCHOOL
}

\author{
Bekjanova Ainura Markhabaevna \\ Senior teacher at the department of social and humanitarian disciplines of the Nukus branch of the \\ Institute of arts and culture of Uzbekistan
}

Article DOI: https://doi.org/10.36713/epra4765

\begin{abstract}
This article considers the history of teaching foreign languages in the conditions of Karakalpakstan, chronologically covering the period from the end of the XIX to the end of the XX centuries. Teaching arabic, then opening Russian-native schools and introducing the Russian language into the program, forming a new education system and teaching German, English and French in schools in Karakalpakstan - here is a list of issues that are addressed in this material. The author tries to carry out a comparative analysis of methods of teaching foreign languages of the pre-Soviet and Soviet periods. This issue is actualized by the fact that during the period when Uzbekistan achieved national independence, this issue has become an urgent task of the educational process.
\end{abstract}

KEY WORDS: education system, mektebs, general education schools, Russian language, foreign languages, methods of teaching.

\section{INTRODUCTION}

In the age of globalization, when geographical boundaries are erased, horizontal relations are increasingly strengthened, cooperation among states, communities and ordinary people is developing, and the world is becoming the most important factor for progress. At the same time, progress is a joint activity, an opportunity to agree and come to a consensus and thus achieve mutual enrichment of cultures and prosperity for all. This can be achieved only by a person who has not only high educational potential, but also has skills in practical communication with representatives of other linguistic cultures.

\section{ANALYSIS}

This is achieved directly through the system of education and training in foreign languages. In accordance with the decision of state bodies throughout Uzbekistan, including Karakalpakstan, a new system of teaching foreign language has been phased in. The main emphasis were placed on the indepth and ubiquitous study of English [1]. Nowadays, English is widely spoken in the world, wider than French, German, Spanish, Russian and Arabic, used as means of international communication. In many states, it was used as a native, second and foreign language, for example,

Arabic, used as means of international communication. In many states, it was used as a native, second and foreign language, for example, English occupied a special place in seventy countries of the world, in nineteen countries it was a state language. In most countries, he is taught at school as the main foreign language, crowding out other foreign languages. In Karakalpakstan, the subject of English was not the first foreign language in the education system. The English language began to be 


\section{EPRA International Journal of Research and Development (IJRD)

taught in our country from the second half of the twentieth century, although the Soviet state paid great attention to the issue of teaching foreign languages and the pre-war period. The existing education system of the pre-revolutionary period included teaching arabic graphics, on the basis of which the Karakalpak literary language was formed. In fact, it was a foreign language, learning went on the basis of simply learning the suras of the Kuran and explaining their meaning. With the accession of part of the territory of modern Karakalpakstan to Russia, they began to open Russian-native schools, which became the basis for the dissemination of Russian language education [2, p. 23-24]. The Russian language began to be taught in jadid schools. During the active struggle for the eradication of illiteracy in the 1930s, the Russian language began to be considered as a language of international communication, there was an active process of training personnel and textbooks for national outskirts. The pre-war period, English, German and French were not paid attention to, since they were not included in the curriculum of the Karakalpak school. Only the post-war period began the process of training foreign language teachers and teaching foreign languages. This issue still remains unexplored, especially since the question of techniques for teaching foreign languages, its methodology, remains out of the field of view of researchers. In our opinion, it was not in demand during the Soviet rule, and the increase in scientific interest in the topic during the period of independence is actualized, first of all, by the urgent need for social development.

\section{METHODS}

The history of teaching foreign languages in the territory of Karakalpakstan dates back more than a century, which were associated with political and economic processes. The first mektebs on the territory of Karakalpakstan were foreign-speaking. Researcher M. Karlibaev writes that "the emergence of mektebs as a muslim school of primary education dates back to the VIII century, when the arab conquerors began to spread their religion - Islam, and with it writing" [3, p. 5].

The famous scientist J. Urumbaev also pointed out that "the training in mektebs was purely religious and scholastic in nature and was reduced to mechanically memorizing the texts of the Qur'an and prayers in Arabic" [4, p. 39]. Such mektebs did not exist either curricula or curricula, there was a simple memorization of arabic words [2, p. 14]. Similar muslim schools existed in Karakalpakstan until the 1930s. Foreign language education in schools in Karakalpakstan continued due to the opening in 1874 a Russian elementary school in the Amudarya department, or rather in Petro-Alexandrovsk. Then, on its basis, the Petro-Alexander City School was opened, in which instruction was conducted in Russian [4, p. 54]. A completely different stage in the history of the practice of teaching foreign languages falls during the years of Soviet power. However, the Russian language for the party-Soviet apparatus was not considered foreign, although it was for the local population. In this perspective, this question has not been studied in historiography. At the same time, a new education system is being formed, German, then English and French, were gradually introduced into the school curriculum as an educational subject. However, in schools in Karakalpakstan, unlike other regions, in addition to Russian, other foreign languages are not studied. From the historiography of the question, it can be noted that the problem of the Soviet system of teaching foreign languages were the lack of practical communication skills, with the exception of the Russian language. At the same time, the teaching methods were the same: translation, grammar-translation, mixed and natural (direct). The general disadvantage in the teaching process in the conditions of schools in Karakalpakstan is the emphasis in teaching on speech, teaching general cultural knowledge without taking into account local characteristics and the national language. It is worth noting that in the schools of the republic, a mono-cultural approach in teaching foreign languages still prevails.

\section{RESULTS AND DISCUSSION}

As you know, the basis for the formation of the written language of local nationalities were arabic graphics, it was also taught in local schools (mektebs). The training was mainly limited to learning the texts of religious books, which was carried out by adding arabic letters. This approach is more reminiscent of the natural method, which was fixed in the works of M. Berlitz and F. Guen, as well as representatives of the direct method of learning straightforward (G. Suit, G. Palmer, etc.).

In this case, they pointed out that in the process of applying this method, a practical goal is set - to teach students to speak a foreign language, when the student follows the heard, imitating the oral speech pattern, that is, imitation and learning [5]. Teaching foreign languages, in particular, the Russian language, especially began to develop rapidly from the end of the 19th century, when there was a need for a large number of people who speak Russian [6]. At the initiative of the tsarist administration, the first 4 schools were opened in the Amu Darya department - the city school in PetroAleksandrovsk [7], women's parish school, and then 


\section{EPRA International Journal of Research and Development (IJRD)}

at the beginning of the twentieth century two Russian-native schools were opened in Chimbai and Shorakhan [2, p. 23]. Judging by some literary materials, in the process of teaching the Russian language in the Russian-native schools of Karakalpakstan, a translation method was used (grammar-translation and vocabulary-translation), when the training is based on the study of grammar and vocabulary. At the beginning of the twentieth century, new-fashioned jadid schools began to open on the territory of Karakalpakstan, where they also taught Russian as foreign. For example, in the Shorakhan school, two hours were allocated daily to the Russian language. The foundations of the Kuran were also studied, elementary knowledge was given in arithmetic, history and geography.In the 1920s, teaching the Russian language as the main issue in the educational process was not, but its teaching took place from the first years of the establishment of Soviet power in Karakalpakstan. In the programs of the first Soviet schools and preparatory courses for teachers, the Russian language was one of the mandatory educational disciplines and was considered as the second after the native language.

In general, in the pre-war period, Russian was not considered as a foreign language in national schools, most likely, it was presented as a second native language. At the same time, teaching the Russian language wore another - political and ideological burden. "Russian language classes should help to educate an active fighter for communism," the document said. "Teaching the second language (in this case, Russian) contributes to international education" [8]. Meanwhile, the central part of the former USSR from the mid-1920s began to implement a new political and cultural campaign "Foreign languages - to the masses!".

The People's Commissariat of Education of the USSR made the teaching of foreign languages mandatory, streamlined the curriculum for foreign languages. A unified system of teaching foreign languages from school to university was developed. In the 1930s, the leadership of the USSR continued to work to strengthen the study of foreign languages. A unified system of teaching foreign languages from school to university was developed. In the 1930s, the leadership of the USSR continued to work to strengthen the study of foreign languages [9, p. 7179]. On August 25, 1932, a decree of the Central Committee of the All-Union Communist Party of Bolsheviks "On curriculum and regime of primary and secondary schools" [10, p. 161-162] was issued, according to which the secondary school was supposed to provide at least one foreign language. Foreign languages recommended for teaching in high school, English, German and French were named.
Two years later, decisions were issued to strengthen the study of foreign languages in technical schools and universities [10, p. 416]. Mainly in the pre-war years, German was taught in about $70 \%$ of educational institutions, in the rest there were subjects of English and French. However, the widespread teaching of foreign languages in the periphery was difficult and in the pre-war period was never implemented. For example, in the conditions of Karakalpakstan, as we indicated above, foreign languages were not at all included in the training program. On September 16, 1940, the Council of People's Commissars of the USSR adopted a resolution "On the teaching of German, English and French", where it recognized the situation with the teaching of foreign languages in schools in the country as unsatisfactory. In this regard, the government proposed to take special measures, in particular, "oblige the People's Commissariat of the Union Republics to introduce the teaching of one foreign language (German, English, French) from grade 5 by 1943 in all secondary schools" [11]. In the post-war period, resolutions of the Council of Ministers of the USSR No. 3488 of October 4, 1947 were adopted, which noted that the study of foreign languages in schools were unsatisfactory. Classes with the study of foreign languages in schools, technical schools and universities gradually began to open, but the lack of personnel did not allow for full work in this direction. In secondary schools of Karakalpakstan until 1954, foreign languages were studied from the third grade, and then from the 5th grade, and there were no specialized schools with indepth foreign languages. On May 27, 1961, the Council of Ministers of the USSR adopted a resolution "On improving the study of foreign languages", which noted that "the teaching of foreign languages in general education schools, in secondary special and higher educational institutions had improved somewhat. However, there are still serious shortcomings in this important matter. The vast majority of graduates of general secondary schools, special secondary schools and higher education institutions have knowledge of foreign language; a small margin of words and formal knowledge of grammar do not allow them to translate foreign text without a dictionary. Speaking skills are particularly inadequate. There are serious shortcomings in the training of foreign language teachers" [12]. Universities were instructed to expand training, textbooks, dictionaries, books, records, educational films were needed for schools [12]. According to the results of the 1961/1962 academic year, several dozen schools with the study of foreign languages were opened in Karakalpakstan [13]. In the 1970-1980s, the Russian language was taught 


\section{EPRA International Journal of Research and Development (IJRD)

from the first grade, and foreign languages from the 5 grade. At the state level, measures were taken to expand quotas for the republic for the training of foreign language teachers, but the need for them remained high.

Meanwhile, in the $1980 \mathrm{~s}$, the methodological base for teaching foreign languages expanded. Methods based on the active work of thinking appear, on the development of a semantic guess, which was based on an audio-lingual skill technique. In the conditions of Karakalpakstan, this method did not have a wide opportunity, since schools lacked not only educational films and records, the technical devices themselves were rare. In teaching foreign languages (English, French, German) was based on a combination of comparative grammar-translation and natural approaches, which suggested explanations in the native language. In the 19701980s, single textbooks were compiled for all schools in the country without taking into account national language differences. They have a large number of translation exercises, the presence in the educational material of texts on the realities and facts of the central part of the country.

The general disadvantage in the teaching process in the conditions of schools in Karakalpakstan is the emphasis in teaching on speech, teaching general cultural knowledge without taking into account local characteristics and the national language. It is worth noting that in the schools of the republic, a monolingual and monocultural approach in teaching foreign languages still prevails.

\section{CONCLUSION}

Today, it is already clear that with the transition to the information stage of the development of a society based on information technology and knowledge, education is becoming the most important resource for socio-economic and political development. The introduction of new didactic and methodological concepts, educational and methodological kits and other means of training, increase the level of instruction, including in foreign languages. To date, the range of methodological innovations had expanded significantly. The expansion of the horizons of communication links allow today to deepen intercultural relations and defined new prospects of educational and methodological tools for teaching foreign languages in the entire structure of educational institutions of Karakalpakstan. In general, this issue is very important in modern conditions, since the educational system is aimed not only at assimilating a certain amount of knowledge, but also at developing the student's personality, cognitive and creative abilities.
It is important for a modern school to form a holistic system of universal knowledge, skills as well as independent activity and personal responsibility, that key competencies determined the modern quality of education. We'll come to the conclusion that foreign languages are an unconditional element of the education of a cultural person, while foreign language has become a means of intercultural communication due to global changes in the political and economic life of our society.

\section{REFERENCES}

1. Decree "On measures to further improve the system of teaching foreign languages" // Newspaper "People's Word". 2012.12.11. №. 240 (5630). The text see: http://www.lex.uz

2. Urumbaev J. About the work of education and briefly about the history of the school in the territory of Karakalpakia before the revolution. Nukus, 1964.

3. Karlibaev M. Madrasah in Karakalpakia of the XIX early XX centuries. Nukus, 2002.

4. Urumbaev J. Essays on the history of schools in Karakalpakstan. Nukus, 1974.

5. Development of foreign language teaching methods abroad // https://studwood.ru/548378/

6. Essays on the history of public education and school in Karakalpakia: Nukus, 1958.

7. Petro-Aleksandrovsk was the administrative center of the Amudarya department of Turkestan Governor General. Then it was renamed the city of Turtkul and became the first capital of the Karakalpak Autonomous Region, now the administrative center of the Turtkul region of the Republic of Karakalpakstan. For more information, see: Nurzhanov S.U. Karakalpak Autonomous Region: history in sources. Nukus, 2014.

8. CSA RK, f.118, i.1, d.30, 9 p.

9. Shelestyuk E.V. Westernization in the USSR and Russia: analysis of some causes // Foreign language in the system of secondary and higher education: materials of the III rd International Scientific and Practical Conference on October 1-2, 2013. Prague, 2013. $216 \mathrm{p}$.

10. Public education in the USSR. Collection of documents. 1917-1973. M., 1974.

11. About teaching German, English and French. Resolution of the Council of People's Commissars of the USSR on September 16, 1940.// http://istmat.info/node/18832

12. On improving the study of foreign languages. Decree of the Council of Ministers of the USSR on May 27, 1961.// http://libussr.ru/doc ussr/usr_5690.htm

13. CSA RK, f. -188, i.4, d.450, 3-7 pp. 